\title{
Çocuklarda Henoch-Schönlein Purpurası: 2 Yıllık Tek Merkez Deneyimi
}

\section{Henoch-Schönlein Purpura in Children: 2 Years of Single Center Experience}

\author{
Mehtap AKBALIK KARA $^{1}{ }^{(\mathbb{D})}$, Beltinge DEMIRCIOĞLU KILIÇ ${ }^{2}{ }^{(\mathbb{D})}$, Mithat BÜYÜKÇELIK ${ }^{2} \mathbb{( D )}$, Ayşe BALAT ${ }^{3}(\mathbb{D})$
}

\author{
1 Diyarbakır Çocuk Hastalıkları Hastanesi, Çocuk Nefroloji kliniği, Diyarbakır, Türkiye \\ 2 Gaziantep Üniversitesi Tıp Fakültesi, Çocuk Nefroloji Bilim Dalı, Gaziantep, Türkiye \\ 3 Aydın Üniversitesi Tıp Fakültesi, Çocuk Nefroloji ve Çocuk Romatoloji Bilim Dall, İstanbul, Türkiye
}

Öz.

Amaç: Henoch-Schönlein purpurası (HSP) tanısı ile izlenen hastaların demografik, klinik ve laboratuvar özelliklerini değerlendirmek ve böbrek tutulumu riski açısından karşılaşıırmak Materyal ve metod: Ocak 2015-Ocak 2017 tarihleri arasında hastanemiz çocuk nefroloji-romatoloji polikliniğinde HSP tanısı konup en az 1 yıl süre ile izlenen hastaların dosyaları gözden geçirildi. Demografik veriler, öykü, tanı yaşı, fizik muayene, laboratuvar tetkikleri, organ tutulumları, böbrek biyopsileri, tüm tedavi rejimleri ve izlemleri değerlendirildi. Bulgular: Çalışmamızda 2 yıllık süre içinde 57'si erkek (\% 48.3) 61'i kız (\% 51.7) toplam 118 hasta vardı. Hastaların yaş ortalaması $7.9 \pm 2.81$, kız: erkek oranı 1: 0.93 idi. 10 yaş ve altında 98 hasta (\% 83.1) varken, 10 yaş üzeri hasta sayısı 20 (\% 16.9) idi. Hastalarda yaş, cinsiyet, hastalık tekrarı, eklem tutulumu yeri ve süresi, döküntünün yeri ve süresi, gastrointestinal tutulum, testis tutulumu, laboratuar parametreleri ile böbrek tutulumu karşılaştırıldığında anlamlı bir ilişki saptanmadı. Sonuç: İki yıllık süre içinde HSP tanısı ile izlediğimiz hastaları geriye dönük olarak değerlendirdiğimizde böbrek tutulumu açısından risk faktörlerine baktığımızda anlamlı bir faktör tespit edemedik. Bu durum bize tüm HSP hastalarının dikkatli bir biçimde böbrek tutulumu açısından takip edilmesi gerektiğini düşündürmektedir.

Anahtar Kelimeler: Çocukluk çağı, Henoch-Schönlein purpurası

\section{Abstract}

Background: To evaluate the demographic, clinical and laboratory characteristics of patients with Henoch-Schönlein purpura (HSP) and compare the risk of renal involvement

Materials and Methods: The files of the patients who were diagnosed as HSP in the pediatric nephrology-rheumatology clinic of our hospital between January 2015 and January 2017 and followed for at least 1 year were reviewed. Demographic data, history, age at diagnosis, physical examination, laboratory tests, organ involvement, renal biopsies, all treatment regimens and follow-up were evaluated.

Results: There were 118 patients 57 male (48.3\%), 61 females (51.7\%) in a 2-year period. The mean age of the patients was $7.9 \pm 2.81$ and the female: male ratio was $1: 0.93$. While there were 98 patients (83.1\%) under 10 years of age, the number of patients over 10 years of age was $20(16.9 \%)$. There was no significant relationship between age, sex, recurrence of disease, location and duration of joint involvement, location and duration of rash, gastrointestinal involvement, testicular involvement, laboratory parameters and renal involvement.

Conclusion: When we retrospectively evaluated the patients, who were followed up with the diagnosis of HSP over a two-year period, we did not find any significant factor in the risk factors for renal involvement. In fact, this suggests that all HSP patients should be carefully monitored for renal involvement.

Key words: Childhood, Henoch-Schönlein purpura 


\section{Giriş}

Henoch-Schönlein purpurası (HSP) çocuklukta en sık görülen vaskülit tipidir (1). HSP, herhangi bir yaşta görülebilse de en sık çocukluk yaş grubunda ortaya çıkan ve sıklıkla kendini sınırlayan bir hastalıktır (2). HSP'de görülen tipik klinik bulgular non-trombositopenik purpura, eklem tutulumu, gastrointestinal sistem tutulumu ve böbrek tutulumudur. Diğer organ tutulumları da nadir olsa da görülebilmektedir (3). Hastalığın kesin nedeni bilinmese de, hastalığı tetikleyen risk faktörleri infeksiyonlar (özellikle üst solunum yolu enfeksiyonları), yiyecekler, ilaçlar, aşılar, ve böcek ISIrıklarıdır (1). Küçük damarlarda immunglobulin A ( $\lg A)$ birikimi ile klinik bulgular ortaya çıkar (4). HSP'de ortaya çıkan en ciddi komplikasyon böbrek tutulumudur (5). En sık görülen renal tutulumlar; izole mikroskobik hematüri ve minimal proteinüri iken nefrotik sendrom ve böbrek yetmezliği daha az görülür (6).

Biz bu çalışmada HSP tanısı ile izlediğimiz hastalarımızı klinik ve laboratuvar özelliklerini, organ tutulumlarını, böbrek tutulumunu etkileyen faktörleri geriye dönük olarak tespit etmeyi amaçladık.

\section{Materyal ve Metod}

Ocak 2015-Ocak 2017 tarihleri arasında hastanemiz çocuk nefroloji-romatoloji polikliniğine başvurup HSP tanısı konup en az 1 yıl süre ile izlenen 118 hasta geriye dönük olarak çalışmaya dahil edildi. HSP tanısı Avrupa Romatizma Birliği (EULAR) tarafından kabul edilen HSP kriterlerine göre tanımlandı (7) (Tablo1). Tanı için tüm hastalarda ciltte purpura ile birlikte aşağıdaki kriterlerden en az birinin olması arandı. Bunlar;

1-Karın ağrısı

2- Artrit veya artralji

3- Histopatolojik olarak lökositoklastik vaskülitin gösterilmesi

\section{4- Böbrek tutulumu}

Tüm hastaların yaş, cinsiyetleri ve hastalığın hangi mevsimde ortaya çıkığı, (kış, sonbahar, ilkbahar, yaz) hangi tetikleyici risk faktörleri sonrasında (üst solunum yolu enfeksiyonu, alt solunum yolu enfeksiyonu, aşı, ilaç ve diğer viral enfeksiyon sonrası, diğer bilinmeyen nedenlerle) görüldüğü değerlendirildi. Tanı yaşı $\leq 10$ yaş ve $>10 y a s ̧$ olan hastalar olarak 2 gruba ayrlıp, yaş ve cinsiyetlerine göre böbrek tutulum ilişkisi değerlendirildi.

Hastaların eklem tutulumları alt ekstremite, üst ekstremite, her iki ektremite ve sadece artraljisi olan hastalar olarak gruplandırıldı. Artrit süreleri 1-3 gün, 4-7 gün ve 7 günden fazla devam eden eklem tutulumu olarak kaydedildi. Artrit süreleri ve tutulum yaygınlığı ile böbrek tutulumunun ilişkili olup olmadığı değerlendirildi.

Erkek çocuklarda testis tulumu olup olmadığı dosya bilgilerinden kaydedilip böbrek tutulumu ile ilişkisine bakıldı.

HSP döküntüsünün yeri (sadece alt ekstremite, alt ve üst ekstremite ve tüm vücut), döküntü süresi (1-5 gün, 5-10 gün, 10-15 gün, 15-30 gün ve 30 günden fazla) ve eğer varsa hastalığın tekrar zamanı (1-3 ay, 4-6 ay, 6-12 ay, 12 yıl) ile böbrek tutulumu ilişkileri gözden geçirildi.

Tablo 1. HSP hastalarının demografik özellikleri

\begin{tabular}{llll}
\hline \multirow{2}{*}{ Cinsiyet } & Erkek & Hasta Sayısı & Yüzdesi (\%) \\
& Kız & 57 & 48.3 \\
Yaş & 10 yaş üstü & 61 & 51.7 \\
& 10 yaş ve altı & 20 & 16.9 \\
\multirow{4}{*}{ Mevsim } & Kış & & 83.1 \\
& Illkbahar & 37 & 31.4 \\
& Yaz & 22 & 18.6 \\
& Sonbahar & 16 & 13.6 \\
& & 43 & 36.4 \\
\multirow{4}{*}{ Tetikleyici faktör } & Üst solunum yolu & & \\
& enfeksiyonu & 88 & 74.6 \\
& Aşı, ilaç,viral enfeksiyon & 3 & 2.5 \\
& Bilinmeyen & 27 & 22.9 \\
\hline
\end{tabular}

Tüm hastalarda tam kan sayımı hemoglobin (hgb), hematokrit (htc), beyaz küre sayısı, nötrofil ve lenfosit sayıları, trombosit sayıları, ortalama trombosit volümü (MPV) sayıları dosya bilgilerinden kaydedildi. MPV değeri $\leq 7.5 \mathrm{fL}$, 7.5-10.5 fL arası ve $\geq 10.6 \mathrm{fL}$ olan hastalarda böbrek tutulum ilişkisine bakıldı. Antinükleer antikor, anti-dsDNA, perinükleer antinükleer sitoplazmik antikor (p-ANCA) kompleman düzeyleri (C3, C4), Anti-streptolizin-O (ASO), IgA düzeyi, C-reaktif protein (CRP) düzeyleri değerlendirildi. C3> $195 \mathrm{mg} / \mathrm{dL}, \mathrm{C} 4>45 \mathrm{mg} / \mathrm{dL}, \mathrm{ASO}>200 \mathrm{IU} / \mathrm{mL}$, IgA $>400 \mathrm{mg} / \mathrm{dL}$ ve CRP>0.5 mg / dL artmış olarak değerlendirildi; C3 $<90 \mathrm{mg} / \mathrm{dL}$ ve $\mathrm{C} 4<10 \mathrm{mg} / \mathrm{dL}$ düşük seviyeler olarak değerlendirildi. Laboratuvar değerleri ile böbrek tutulumu arasında ilişki karşılaştırıldı.

Böbrek tutulumu olarak; sadece hematüri olması (idrar sedimentinde mikroskobik olarak her büyük büyütme alanında 5 'ten fazla eritrosit olması veya dipstikte $\geq 1+$ eritrosit varlığı), proteinüri olması (spot idrarda protein/kreatinin oranının 2 yaşından küçük çocuklarda $>0.5 \mathrm{mg} / \mathrm{mg}, 2$ yaşından büyük çocuklarda $>0.2 \mathrm{mg} / \mathrm{mg}$ olması, 24 saatlik idrarda $>4 \mathrm{mg} / \mathrm{m} 2 /$ saat olması), hematüri ve proteinürinin birlikte olması veya nefrotik düzeyde proteinüri ( 24 saatlik idrarda $\geq 40 \mathrm{mg} / \mathrm{m}^{2} / \mathrm{saat}$, spot idrarda protein $/ \mathrm{Cr}>2$ $\mathrm{mg} / \mathrm{mg}$ ) olması şeklinde tanımlandı (8).

Böbrek biyopsisi nefrotik düzeyde proteinürisi olan hastalara veya nefrotik sendromu olan olgulara, makroskobik hematürisi, hipertansiyonu veya akut böbrek yetmezliği olan hastalara yapıldı. Böbrek biyopsi örnekleri Uluslararası Çocuklarda Böbrek Hastalığı Çalışma Grubu (ISKDC) tarafindan sınıflandırmaya uygun olarak evreleme yapıldı (9). Buna göre histopatolojik evre, tedavi protokolü, tedavi süresi ve klinik gidiş bilgileri kaydedildi.

Çalışmamız 1983' te revize edilmiş 1975 Helsinki deklarasyonuna uygun olarak üniversitemiz yerel etik kurul onayı alındıktan sonra (06.02.2017 tarihinde 2017/42 sayılı karar ile) hazırlanmıştır. 


\section{İstatistiksel Yöntem}

Elde edilen veriler SPSS Statistics (Software Vers. 22.0) programı ile değerlendirildi. Kolmogorov-Smirnov ile verilerin dağılımına bakıldı. Student T test ile nicel verilerin ortalamaları istatistiksel olarak karşılaştırıldı. Kategorik değişkenlerin karşılaştırıması için Ki- kare Testi kullanıldı ve tüm testlerde $p<0.05$ olan değerler istatistiksel olarak anlamlı kabul edildi.

\section{Bulgular}

Çalışmamıza 2 yıllık süre içinde 57 'si erkek (\% 48.3) 61'i kIz (\% 51.7) toplam 118 hasta dahil edildi. Hastaların yaş ortalaması $7.9 \pm 2.81$, kız: erkek oranı 1:0.93 idi. 98 hastanın (\% 83.1) 10 yaş ve altında, 20 (\% 16.9) hastanın 10 yaş üzerinde tanı aldığı görüldü. HSP tanısı konan hastaların başvuru mevsimlerine bakıldığında; 16 olgu (\% 13.6) yaz mevsiminde, 22 olgu (\% 18.6) ilkbahar mevsiminde, 43 olgu (\% 36.4) sonbahar mevsiminde,37 olgu (\% 31.4) kış mevsiminde tanı aldı. Tüm olgulara bakıldığında hastaların \% 67.8'inin sonbahar ve kış aylarında tanı aldığı görüldü. Hastalığı tetikleyici faktörler değerlendirildiğinde en sık olarak 88 olguda (\% 74.6) bir üst solunum yolu enfeksiyonu sonrası HSP geliştiği görüldü. Aşı sonrası sadece 1 olguda (\% 0.8), su çiçeği enfeksiyonu sonrası ise 2 olguda (\% 1.7) HSP geliştiği görüldü. Geri kalan 27 olguda (\% 22.9) ise herhangi bir tetikleyici faktör tespit edilemedi. Hastaların demografik özellikleri tablo 1'de gösterilmiştir.

HSP tanısı konan hastaların döküntüleri incelendiğinde 83 hastada (\% 70.3) sadece alt ekstremitede döküntü, 31 olguda (\% 26.3) hem alt hem de üst ekstremitede döküntü, 4 olguda (\% 3.4) yüz, kulak sayvanı ve boyun dahil tüm vücutta döküntü mevcuttu. Döküntülerin süresine bakıldığında; 1 olguda (\% 0.9) 1-5gün, 29 olguda (\% 24.8) 5-10 gün, 30 olguda (\% 25.6) 10 -15 gün, 35 olguda (\% 29.9) 1530 gün, 23 olguda (\% 18.8) 1 aydan fazla sürdüğü saptandı. HSP tanısı ile izlediğimiz 118 hastanın 104'ünde (\% 88.9) hastalık ve döküntü tekrarlamazken, 5 hastada (\% 4.2) 3 ay içinde, 3 hastada (\% 2.3) 3-6 ay içinde, 3 hastada (\% 2.3) 6 ay-1 yıl içinde, 3 hasta da (\% 2.3) $1-2$ yıl içinde HSP tekrarı görüldü.

Gastrointestinal tutulum açısından 118 hasta değerlendirildiğinde tüm hastalarda GiS tutulumu vardı. 103 hastada (tüm hastaların \% 87.3'ünde) karın ağrısı, 39 hastada (tüm hastaların \% 33.1'inde) kusma, 47 hastada (tüm hastaların $\% 39.8^{\prime}$ inde) melena mevcuttu. Bazı hastalarda birden fazla GiS tutulumu mevcuttu. Bir hastada invajinasyon saptandı (\% 0.84). Çocuk cerrahi tarafından kapalı redüksiyon uygulandı. 57 erkek hastanın 6'sında $(\% 10.5)$ testis tutulumu vardı.

Eklem tutulumları göz önünde bulundurulduğunda 106 hastada (\% 88.1) eklemde artrit bulguları varken 12 hastada (\% 10.2) artralji vardı. 76 hastada (\% 64.4) sadece alt ekstremitede, 3 hastada (\% 2.5) sadece üst ekstremitede, 27 hastada (\% 22.9) hem alt, hem üst ekstremitede artrit bulguları varken, 12 hastada (\% 10.2) sadece artralji mevcuttu. Artrit sürelerine bakıldığında 19 hastada (\% 15.4) 1 3 gün, 59 hastada (\% 50.4) $4-7$ gün, 40 hastada (\% 34.2) 7 günden daha uzun süre devam ettiği saptandı.

Tablo 2: Hastaların klinik özellikleri

\begin{tabular}{ll} 
Klinik bulgular & Hasta sayısı (\%) \\
\hline Purpura & $118(100)$ \\
Alt ekstremite & $83(70.3)$ \\
Alt + üst ekstremite & $31(26.3)$ \\
Tüm vücut & $4(3.4)$ \\
& \\
Eklem tutulumu & $118(100)$ \\
Artrit $\quad$ & $76(64.4)$ \\
Alt ekstremite & $3(2.5)$ \\
Üst ekstremite & $27(22.9)$ \\
Alttüst ekstremite & $12(10.2)$ \\
Artralji & $118(100)$ \\
Gastrointestinal tutulum & $103(87.3)$ \\
Karın ağrısı & $39(33.1)$ \\
Kusma & $47(39.8)$ \\
Melana & $1(0.84)$ \\
İnvajinasyon & $31(26.3)$ \\
Renal & $7(5.9)$ \\
Mikroskobik hematüri & $3(2.54)$ \\
Makroskobik hematüri & $21(17.7)$ \\
Nefrotik proteinüri & $6(10.5)$ \\
Testis (erkek) & \\
&
\end{tabular}

Böbrek tutulumlarına bakıldığında 118 hastanın 31'inde (\% 26.3) böbrek tutulumu varken geri kalan 87 hastada (\% 73.7) böbrek tutulumu saptanmadı. Böbrek tulumu olan hastaların 7'sinde (\% 5.9) sadece mikroskobik hematüri, 3'ünde (\% 2.54) makroskobik hematüri, 21'inde (\% 17.7) nefrotik proteinüri saptandı. Böbrek tutulumu olan hastaların 27 'sinde (\% 23.1) ilk bir ay içinde klinik ve laboratuar bulgular saptanırken geri kalan 4 hastada (\% 3.4) böbrek tutulumu ilk 1-3 ay içinde görüldü. Renal tutulumu olan 31 hastanın 23 'üne böbrek biyopsisi yapıldığı diğer 8 hastaya biyopsi yapılmadığı saptandı. 2 hastada makroskobik hematüri, akut nefritik sendrom tablosu, 21 hastada nefrotik düzeyde proteinüri nedeni ile böbrek biyopsisi yapıımıştı. Renal biyopsi evrelerine göre biyopsi yapılan 23 hastanın 1'inde evre 1, 11'inde evre 2, 11'inde evre 3 biyopsi bulguları saptandı.

Hastaların klinik özellikleri tablo 2'de gösterilmiştir.

Laboratuvar bulguları değerlendirildiğinde HSP hastalarımızın tümünde kompleman 3 (C3) düzeyi normal iken 1 hastada kompleman 4 (C4) düzeyi sınırda düşük saptandı. CRP düzeyleri 35 hastada (\% 29.7) yüksek iken geri kalan 83 hastada (\% 70.3) normaldi. ASO düzeyi 26 hastada (\% 22) yüksek iken diğer hastalarda normal düzeylerde idi. Tüm hastalarda IgA düzeyi normal iken sadece bir hastada (\% 0.84) düşük saptandı. Bu hastanın takibinde tekrarlanan IgA düzeyi normaldi.

Böbrek tutulum açısından risk faktörleri değerlendirildi. Renal tutulum ile cinsiyet arasında bir ilişki olmadığı görüldü (p:0.680). Hastalar $\leq 10$ yaş ve $>10$ yaş olarak kategorize 
edildiğinde; yine renal tutulumu ile bu iki grup arasında istatistiksel olarak anlamlı bir ilişki saptanmadı (p:0.240). Döküntü süresinin uzun olması, hastalık tekrarı oranı, testis tutulumu, GiS tutulumu, eklem tutulumunun yeri, artrit süresi ile böbrek tutulumu arasındaki ilişki değerlendirildiğinde de anlamlı bir ilişki saptanmadı (sırasıyla; p:0.809, p:0.602, p:0.707, p:0.657, 0.999, 0.680). Laboratuvar değerleri ile böbrek tulumu arasındaki ilişki değerlendirildiğinde de CRP düzeyinin yüksek olması, MPV değerlerinin $\leq 7,5 \mathrm{fL}$ 7,6-10.5fL arası ve $\geq 10.6 \mathrm{fL}$ olması ile böbrek tutulumu arasında anlamlı bir ilişki saptanmadı ( $\mathrm{p}: 0.199$, $\mathrm{p}: 0.743$ ). Klinik ve laboratuvar bulgularının böbrek tutulumuna etkisinin değerlendirilmesi tablo 3 'te gösterilmiş̧tir.

Tedavi açısından hastalar değerlendirildiğinde tüm hastalara yatak istirahati, uygun beslenme şekli, non-steroid anti-inflamatuar ilaçlar verildi. Toplam 50 hastaya kortikosteroid tedavisi verildi. Steroid tedavisi verilen 50 hastanın 23'üne böbrek tutulumu nedeni ile verilirken, 27 hastaya gastrointestinal tutulum nedeni ile verildi. Renal biyopsi yapllıp steroid tedavisi verilen hastalardan 4'üne 2 ayın sonunda proteinürinin devam etmesi nedeni ile siklofosfamid, 9 'una siklosporin-A tedavisi verildi. Toplamda 9 hastaya 30 $\mathrm{mg} / \mathrm{kg} / \mathrm{gün}$ dozunda 3-6 kez pulse metilprednizolon tedavisi verildi. Hastaların en az 1 yıllık süre sonundaki takiplerinde hiçbir hastada böbrek fonksiyon testlerinde bozukluk ve/veya proteinüri saptanmadı.

Tablo 3. Klinik ve laboratuvar bulgularının böbrek tutulumuna etkisinin değerlendirilmesi

\begin{tabular}{|c|c|c|c|c|}
\hline & & \multicolumn{2}{|c|}{ Böbrek tutulumu } & \multirow[b]{2}{*}{$p$} \\
\hline & & $\operatorname{Var}(n=31)$ & Yok $(n=87)$ & \\
\hline \multirow[t]{2}{*}{ Yaş grupları } & $\leq 10$ yaş & $21(\% 23,6)$ & $68(\% 76,4)$ & \multirow{2}{*}{0.240} \\
\hline & 10 yaş üstü & $10(\% 34,5)$ & $19(\% 65,5)$ & \\
\hline \multirow[t]{2}{*}{ Cinsiyet } & $\mathrm{KIz}$ & $17(\% 27,9)$ & $44(\% 72,1)$ & \multirow{2}{*}{0.680} \\
\hline & Erkek & $14(\% 24,6)$ & $43(\% 75,4)$ & \\
\hline \multirow[t]{5}{*}{ Döküntü Süresi } & 1-5 gün & $0(\% 0)$ & $1(\% 100)$ & \multirow{5}{*}{0,809} \\
\hline & 5-10 gün & $6(\% 20)$ & $23(\% 80)$ & \\
\hline & 10-15 gün & $8(\% 25,6)$ & $22(\% 74,4)$ & \\
\hline & 15-30 gün & $9(\% 25,7)$ & $26(\% 74,3)$ & \\
\hline & 30 günden fazla & $8(\% 31,8)$ & $15(\% 68,2)$ & \\
\hline \multirow[t]{2}{*}{ CRP } & Normal & $19(\% 22,9)$ & $64(\% 77,1)$ & \multirow{2}{*}{0.199} \\
\hline & Yüksek & $12(\% 34,3)$ & $23(\% 65,7)$ & \\
\hline \multirow[t]{3}{*}{ Artrit Süresi } & 1-3 gün & $4(\% 16,7)$ & $15(\% 83,3)$ & \multirow{3}{*}{0.680} \\
\hline & \begin{tabular}{|l|} 
4-7 gün \\
\end{tabular} & $13(\% 22)$ & $46(\% 78)$ & \\
\hline & 7 günden sonra & $14(\% 35)$ & $26(\% 65)$ & \\
\hline \multirow{4}{*}{$\begin{array}{c}\text { Eklem Tutulum } \\
\text { Yeri }\end{array}$} & Alt Ekstremite & $19(\% 25)$ & $57(\% 75)$ & \multirow{4}{*}{0.999} \\
\hline & Üst Ekstremite & $0(\% 0)$ & $3(\% 100)$ & \\
\hline & Her ikisi & $9(\% 33,3)$ & $18(\% 66,7)$ & \\
\hline & Sadece Artralji & $3(\% 25)$ & $9(\% 75)$ & \\
\hline \multirow[t]{3}{*}{ MPV } & 7.5 fLden az & $2(\% 22,2)$ & $7(\% 77,8)$ & \multirow{3}{*}{0.743} \\
\hline & 7.5-10.5fL arası & $24(\% 28,2)$ & $61(\% 71,8)$ & \\
\hline & 10.6fLden fazla & $5(\% 20,8)$ & $19(\% 79,2)$ & \\
\hline
\end{tabular}

CRP: C-reaktif protein, n: Hasta sayıII, MPV: Ortalama trombosit volümü

\section{Tartışma}

Henoch-Schönlein purpurası çocukluk çağında en sık 2-10 yaş arası görülen vaskülit tipidir (10). Literatürde erkek/kız oranı 1.3/2 oranında bildirilirken bazı çalışmalarda kız/erkek oranı 1.2/1 olarak bildirilmiştir (11). Bizim çalışma- mızda da benzer şekilde kız/erkek oranı 1/0.93 idi. Çalışmamızda 10 yaş altı hasta sayısı \% 83.1 olup ortalama tanı yaşı $7.9 \pm 2.81$ idi. Hastalarımızın başvuru mevsimlerine bakıldığında en çok sonbahar ve kış aylarında tanı aldıkları görülmektedir. Tüm olguların \% 67.4'ü sonbahar ve kış aylarında başvurmuş olup bu sonuç literatürdeki çalışmalarla benzerdir $(12,13)$. Çalışmamızda hastalığı tetikleyen faktörler içinde en sık bir üst solunum yolu enfeksiyonu mevcutken, 3 hastada aşı ve viral enfeksiyon sonrası, geri kaIan 27 hastada herhangi bir belirleyici etken bulunamamıştır. Literatürde yer alan çalışmalarda da en sık saptanan faktör bir üst solunum yolu enfeksiyonu sonrası hastalığın görülmesidir (1). Sonbahar ve kış aylarında hava değişikliklerinin daha fazla olması ve bu mevsimlerde çocuklarda enfeksiyonların daha fazla görülmesi önemli bir nedendir $(1,12,13)$.

Tüm hastalarda ilk başvuru döküntü ile olmuştur. 83 hastada (\% 70.3) sadece alt ekstremitede döküntü, 31 olguda (\% 26.3) hem alt hem de üst ekstremitede döküntü, 4 olguda (\% 3.4) yüz, kulak sayvanı ve boyun dahil tüm vücutta döküntü mevcuttu. Döküntülerin süresine bakıldığında; 1 olguda (\% 0.9) 1-5 gün, 29 olguda (\% 24.8) 5-10 gün, 30 olguda (\% 25.6) $10-15$ gün, 35 olguda (\% 29.9) 15-30 gün, 23 olguda (\% 18.8) 1 aydan fazla sürdüğü saptandı. Döküntü süresinin uzun olması ile böbrek tutulumu değerlendirildiğinde anlamlı bir ilişki saptanmadı (p:0.809). Rigante ve arkadaşlarının yaptığı bir çalışmada döküntü süresinin 30 günden uzun olması tek başına hastalık tekrarı ve böbrekte sekel açısından bir risk faktörü olarak görülmüştür. Vasküler inflamasyon ve immün kompleks birikimi olmasının böbrek tutulumunu tetikleyen muhtemel bir faktör olduğu düşünülmüştür (14). Bizim çalışmamızda bu ilişkinin saptanmamasının hasta sayısının az olması ile ilişkili olabileceği düşünülmüştür. HSP tanısı ile izlediğimiz 118 hastanın 104'ünde (\% 88.9) hastalığa ait tekrar görülmezken 14 hastada (\% 11) HSP tekrarı görülmüştür. Aynı şekilde hastalık tekrarı ile böbrek tutulumu arasında da anlamlı bir ilişki saptanmamıştır. (p:0.602).

Gastrointestinal tutulum açısından 118 hasta değerlendirildiğinde 103 hastada (\% 87.3) karın ağrısı, 39 hastada (\% 33.1) kusma, 47 hastada (\% 39.8) melena mevcuttu. Tüm hastalarda GiS tutulum görülürken bazı hastalarda birden fazla GiS tutulum vardı. Bir hastada invajinasyon saptandı. Karın ağrısı, kusma ve melena gastrointestinal tutulumlar içinde en sık görülen tutulumlardır $(11,15,16)$. Birçok çalışmada gastrointestinal tutulum oranları yüksektir $(1,11)$. Gastrointestinal tutulumu ile böbrek tutulumu arasındaki ilişkiye bakıldığında anlamlı bir ilişki saptanmamıştır ( $\mathrm{p}: 0.657$ ). Literatürde de benzer şekilde gastrointestinal tutulum ile böbrek tutulumu arasında çalışmamızda olduğu gibi anlamlı ilişki saptanmayan çalışmalar olduğu görülmüştür $(14,17)$. Zhao ve arkadaşlarının yaptığı bir çalışmada da karın ağıısı ile HSP de böbrek tutulumu arasında 
bir korelasyon olmadığını saptamışlardır (18). Ancak literatürde GiS tutulumu ile böbrek tutulumu arasında ilişki olduğunu saptayan çok sayıda çalışma olduğu da görülmüştür (19).

Testis tulumu \% 2-38 arasında olup (20), bizim çalışmamızda bu oran \% 10.5 olarak saptanmıştır. Çalışmamızda testis tutulumu ile böbrek tutulumu arasında ilişki saptanmamıştır (p:0.707) Literatürde de bu ilişkinin olmadığını gösteren çalışmalar olduğu gibi (17) bu ilişkinin olduğunu gösteren çalışmalar da saptanmıştır (21).

Eklem tutulumları göz önünde bulundurulduğunda 106 hastada (\% 88.1) eklemde artrit bulguları varken 12 hastada (\% 10.2) artralji vardı. 76 hastada (\% 64.4) sadece alt ekstremitede, 3 hastada (\% 2.5) sadece üst ekstremitede, 27 hastada (\% 22.9) hem alt hem üst ekstremitede artrit bulguları varken, 12 hastada sadece (\% 10.2) artralji mevcuttu. Literatüre baktığımızda da benzer biçimde en sık alt ekstremitede artrit bulguları olduğu görülmüştür $(1,12)$. Eklem tutulumunun lokalizasyonu ve artrit süresinin uzaması ile böbrek tutulumu arasında da ilişki olmadığı görülmüştür (p:0.999, p:0.680).

Laboratuar sonuçlarını değerlendirdiğimizde CRP yüksekliği ve son yıllarda sıklıkla çalışmalarda yer alan MPV değerleri ile böbrek tutulumu arasında ilişki olup olmadığına baktık. Literatürde yüksek MPV ve CRP değerleri ile böbrek tutulumu arasında ilişki olduğunu gösteren çalışmalar bulunmaktadır $(17,22)$. Biz çalışmamızda CRP yüksekliği ve yüksek MPV değerleri ile böbrek tutulumu arasında anlamlı bir ilişki saptamadık (p:0.199, p:0.473).

Böbrek tutulumlarına bakıldığında 118 hastanın 31 'inde (\% 26.3) böbrek tutulumu varken geri kalan 87 hastada (\% 73.7) böbrek tutulumu saptanmadı. Böbrek tutulumu olan hastaların 27'sinde ilk bir ay içinde klinik ve laboratuar bulgular saptanırken geri kalan 4 hastada böbrek tutulumu ilk 1-3 ay içinde görüldü. Literatürdeki çalışmalarda da renal tutulum en sık ilk 1 ay içinde gözükmektedir (17). Renal tutulumu olan 31 hastanın 23'üne böbrek biyopsisi yapıdığı sadece mikroskobik hematüri olan 8 hastaya biyopsi yapılmadığı saptandı. 2 hastada nefrotik sendrom bulguları, 2 hastada makroskobik hematüri, akut nefritik sendrom tablosu, 19 hastada nefrotik düzeyde proteinüri nedeni ile böbrek biyopsisi yapıımıştı. Renal biyopsi evrelerine göre biyopsi yapılan 23 hastanın 1 'inde evre 1, 11'inde evre 2, 11 'inde evre 3 biyopsi bulguları vardı. Sano ve arkadaşlarının yaptığı çalışmada başvuruda böbrek tutulumunun ağırlığı ve nefrotik proteinürinin ağırlığının en önemli prognostik faktör olduğu saptanmıştır (23). Bazı çaIışmalarda ise esas prognostik faktörün biyopside histopatolojik bulguların ağırlığı olduğu ifade edilmiştir (24). Son dönem böbrek yetmezliğinin hastaların yaklaşık \%1 inde görülebildiği tahmin edilmektedir (25). Renal biyopsi yapılıp steroid tedavisi verilen hastalardan 4'üne 2 ayın sonunda proteinürinin devam etmesi nedeni ile siklofosfamid, g'una siklosporin-A tedavisi verildi. Hastaların en az 1 yıllık süre sonundaki takiplerinde hiçbir hastada böbrek fonksiyon testlerinde bozukluk ve/veya proteinüri saptanmadı. Hastalarımızın böbrek biyopsi evrelerinin evre1- evre 3 arası olması, evre 4 ve evre 5 hastamızın olmaması uzun dönem takiplerinde proteinürilerinin olmaması ve böbrek fonksiyonlarında bozukluk olmaması açısından bir neden olabilir.

Sonuç olarak; iki yıllık süre içinde HSP tanısı ile izlediğimiz hastaları geriye dönük böbrek tutulumu açısından risk faktörlerine baktığımızda anlamlı bir faktör tespit edemedik. Bu durum bize tüm HSP hastalarının dikkatli bir biçimde en önemli morbidite olan renal tutulum açısından takip edilmesi gerektiğini düşündürmekle birlikte çalışmamızın geriye dönük olması ve hasta sayısının sınırlı olması kısıtlayıcı unsurlardır. Literatürde varolan çalışmalarda inflamasyon göstergelerinin renal tutulum açısından risk faktörü olduğunu gösteren çalışmalar olsa da biz yine de tüm hastaların dikkatle takip edilmesi gerektiğini düşünmekteyiz.

\section{Açıklamalar \\ Çıkar çatışması beyanı: Yazarlar çıkar çatışması olmadı- ğını bildirmişlerdir.}

Finansal destek : Bu çalışma herhangi bir fon tarafından desteklenmemiştir.

Etik kurul onayı : 06.02.2017-2017/42 sayılı karar ile Gaziantep Üniversitesi Tıp Fakültesi etik kurulu onayı alınmıştır.

\section{Kaynaklar}

1. Wang X, Zhu Y, Gao L, Wei S, Zhen Y, Ma Q. Henoch-Schönlein purpura with joint involvement: Analysis of 71 cases. Pediatric Rheumatology. 2016;14(1):20.

2. Saulsbury FT. Henoch-Schönlein purpura. Curr Opin Rheumatol. 2001;13(1):35-40.

3. Chen J, Fang X, Dang X, Wu X, Yi Z. Association of the paired box 2 gene polymorphism with the susceptibility and pathogenesis of Henoch Schönlein purpura in children. Mol Med Rep. 2015;11(3): 1997-2003.

4. Zaffanello $M$, Brugnara $M$, Franchini $M$. Therapy for children with henoch-schonlein purpura nephritis: a systematic review. Scientific World Journal. 2007; 10(7): 20-30.

5. Jauhola O, Ronkainen J, Autio-Harmainen H, Koskimies O, Ala-Houhala M, Arikoski P, et al. Cyclosporine A vs. methylprednisolone for Henoch-Schönlein nephritis: a randomized trial. Pediatr Nephrol. 2011; 26(12): 2159-66.

6. Chen JY, Mao JH. Henoch-Schönlein purpura nephritis in children: incidence, pathogenesis and management.World $\mathrm{J}$ Pediatr. 2015;11(1):29-34.

7. Ozen S, Pistorio A, lusan SM, Bakkaloglu A, Herlin T, Brik R, et al; Paediatric Rheumatology International Trials Organisation (PRINTO).EULAR/PRINTO/PRES criteria for Henoch-Schönlein purpura, childhood polyarteritis nodosa, childhood Wegener granulomatosis and childhood Takayasu arteritis: Ankara 2008. Part II: Final classification criteria. Ann Rheum Dis. 2010;69(5):798-806.

8. Lee YH, Kim YB, Koo JW, Chung JY. Henoch-Schonlein Purpura in Children Hospitalized at a Tertiary Hospital during 2004-2015 in Korea: Epidemiology and Clinical Management.Pediatr Gastroenterol Hepatol Nutr. 2016;19(3):175-185.

9. Counahan R, Winterborn MH, White RH, HeatonJM, Meadow SR, Bluett $\mathrm{NH}$, et al. Prognosis of Henoch-Schönlein nephritis in children. $\mathrm{Br}$ 
Med J.1977; 2:11-4

10. Ozen S. The spectrum of vasculitis in children. Best Pract Res Clin Rheumatol. 2002; 16(3):411-25.

11. Calviño MC, Llorca J, García-Porrúa C, Fernández-Iglesias JL, Rodriguez-Ledo P, González-Gay MA. Henoch-Schönlein purpura in children from northwestern Spain: A 20-year epidemiologic and clinical study. Medicine (Baltimore). 2001;80(5): 279-90.

12. Trapani S, Micheli A, Grisolia F, Resti M, Chiappini E, Falcini F, et al. Henoch Schonlein purpura in childhood: epidemiological and clinical analysis of 150 cases over a 5-year period and review of literature. Semin Arthritis Rheum. 2005;35(3):143-53.

13. Nong BR, Huang YF, Chuang CM, Liu CC, Hsieh KS. Fifteen-year experience of children with Henoch-Schönlein purpura in southern Taiwan, 1991-2005. J Microbiol Immunol Infect. 2007:40(4):371-6.

14. Rigante D, Candelli M, Federico G, Bartolozzi F, Porri MG, Stabile A. Predictive factors of renal involvement or relapsing disease in children with Henoch-Schönlein purpura. Rheumatol Int. 2005; 25(1): 45-8. 15. Chen O, Zhu XB, Ren P, Wang YB, Sun RP, Wei DE. Henoch Schonlein Purpura in children: clinical analysis of 120 cases. Afr Health Sci. 2013;13(1): 94-9.

16. Anil M, Aksu N, Kara OD, Bal A, Anil AB, Yavaşcan O, et al. HenochSchönlein purpura in children from western Turkey: a retrospective analysis of 430 cases. Turk J Pediatr. 2009;51(5): 429-36.

17. Demircioğlu Kiliç B, Kasap Demir B. Determination of Risk Factors in Children Diagnosed With Henoch-Schönlein Purpura. Arch Rheumatol. 2018; 33(4):395-401.

18. Zhao YL, Liu ZJ, Bai XM, Wang YC, Li GH, Yan XY. Obesity increases the risk of renal involvement in children with Henoch-Schönlein purpura.Eur J Pediatr. 2015;174(10):1357-63.

19. Chan H, Tang YL, Lv XH, Zhang GF, Wang M, Yang HP, et al. Risk Factors Associated with Renal Involvement in Childhood HenochSchönlein Purpura: A Meta-Analysis.PLoS One. 2016; 11(11): e0167346.

20. Lim Y, YiBH, Lee HK, Hong HS, Lee MH, Choi SY, et al. HenochSchonlein purpura: ultrasonography of scrotal and penile involvement. Ultrasonography. 2015;34(2):144-147.

21. Tabel Y, Inanc FC, Dogan DG, Elmas AT. Clinical features of children with Henoch-Schonlein purpura: risk factors associated with renal involvement.Iran J Kidney Dis. 2012; 6(4):269-74.

22. Elmas AT, Tabel Y. Platelet Counts in Children With Henoch-Schonlein Purpura--Relationship to Renal Involvement. J Clin Lab Anal. 2016; 30(1):71-4.

23. Sano $H$, Izumida $M$, Shimizu $H$, Ogawa $Y$. Risk factors of renal involvement and significant proteinuria in Henoch-Schönlein purpura. Eur J Pediatr. 2002;161(4):196-201.

24. Amore A, Camilla R, Coppo R. News on the etiopathogenesis and the treatment of Schoenlein-Henoch nephritis. Minerva Pediatr. 2009;61(6):729-33.

25. Yin XL, Zou MS, Zhang Y, Wang J, Liu TL, Tang JH, et al. Twentythree-year review of disease patterns from renal biopsies: an experience from a pediatric renal center. J Nephrol. 2013;26(4):699-707. 